
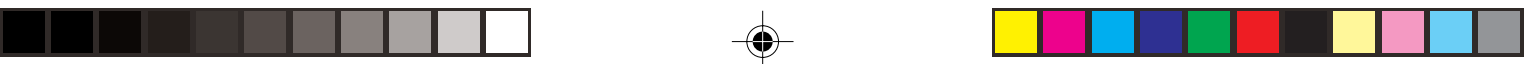

\title{
REPLIK
}

\section{TIL PERNILLE GYLLING JØRGENSEN}

\begin{abstract}
Man tager altid ungdommens forvildelser i betragtning, men regner ikke med alderdommens desillusioner [...] når jeg bliver konservativ med årene, så gennemgår jeg en normal forandringscyklus. [...] Det finder jeg mig i, som jeg må finde mig i gigt eller gråt hår, som et ledsagefænomen til stigende alder eller svigtende animalsk varme, men jeg erkender ikke, at det nødvendigvis er en forandring til det bedre... (Robert Louis Stevenson).
\end{abstract}

I tidsskriftets milleniumnummer skrev jeg et essay om markedssystemets sejr og udbredelse over den ganske verden og om økonomers og nyliberalisters stigende ideologiske og reelle magt. En stor del af artiklen handlede om kapitalistisk økonomi og dens udøvere, men jeg spurgte også, om man kunne tænke sig, at denne samfundsudvikling satte sig spor i samfundsvidenskaberne, specielt antropologien. Det mente jeg, at man kunne, og imellem de tendenser, jeg nævnte, var også henvisninger til postmodernismen. Det har udfordret Pernille Gylling Jørgensen, som i pagt med tidens tilskyndelser har antaget postmodernismen som sin faglige trosbekendelse. Hun kritiserer mig for at afvise postmodernismen på et forkert og for snævert grundlag. Desuden er jeg bagefter. Mine ærgrelser er forsinkede, og mit syn tilhører en anden tid. Jørgensen påpeger med ungdommens mangel på skånsel, at min artikel er trykt i forrige århundrede.

I det ungdomsessays om „Knarvorn alderdom og ungdommen“, som jeg citerer til indledning, forsvarer Robert Louis Stevenson ungdommens ret til sin egen mening. Når Pernille Gylling Jørgensen derfor forsvarer den postmodernisme, hun har ladet sig begejstre af, ville det være ubilligt af mig at desavouere hendes ret til at tilslutte sig et nyt videnskabssyn. På den anden side vil jeg knarvornt forbeholde mig min ret til at forsvare og forklare mit.

Jørgensen mere end antyder, at min kritik af postmodernismen bygger på et begrænset kendskab til den. Og det skal såmænd nok være rigtigt. Alligevel befinder jeg mig, som hun nævner, i følgeskab med Habermas og Ulrich Beck, og det synes jeg nu ikke, er det værste selskab. Hun fremdrager selv postmoderne forskere, som hun kritiserer for æsteticering (Clifford) eller individfokusering (Rapport), to holdninger, som var genstand for min kritik. Når hun derefter fremhæver en ,,velfunderet postmoderne antropologi“, der „,fokuserer på [...] institutioner, magtforhold og [...] politik, samtidig med at den beskæftiger sig med, hvordan mennesker lever, reproducerer og udfordrer disse forhold“", kan jeg jo ikke tage afstand. Der tegner sig ligefrem en fælles mødeplads, hvor vi er enige. Måske er det sådan, at der er en ,dårlig" og en ,god" postmoderne antropologi; 

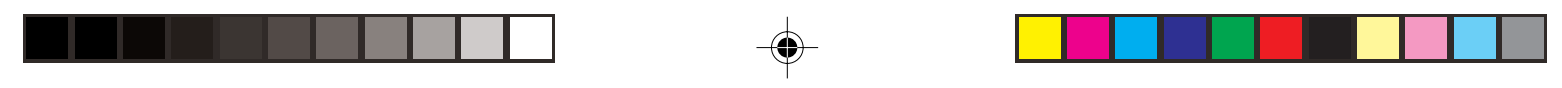

at det kommer an på, hvordan man bruger postmoderne indsigter. Men helt enige kan vi nu ikke blive, for det kommer også an på, hvordan man forstår disse indsigter.

Ifølge Jørgensens forståelse af postmodernismen går den ud på, at ,virkeligheden“ ”er socialt konstrueret, at den menneskelige væren er karakteriseret af tilfældighed og tilblivelse, og at „sandheden“ er diskursiv. Der er ifølge Rapport, som hun citerer, ,ingen mening [...] men uendeligt mange meninger“, da ,verden kan fortolkes lige godt på umådeligt forskellige [...] måder, idet dens 'fakta' bliver konstrueret og ikke opdaget". En vigtig postmoderne pointe er at ,[m]enneskers liv, historiens gang, samfundets form etc. altid har været usikker og foranderlig og aldrig besiddet nogen forudbestemt retning eller essens“. Og det betyder et „opgør med vestlig universalisme, objektivitet og rationalitet", skriver Jørgensen. Men sådan et billede af tilværelsen forkommer mig netop retningsløst. Og jeg tror, det er fordi, det binder sig til at anskue verden fra menneskemylderets umiddelbare niveau af handlinger og tilskyndelser. Her, hvor konkrete individer gør deres ting og konstruerer deres virkeligheder, er der en høj grad af ubestemthed. Men hæver man sig op over dette mêlée, er det muligt at tale meningsfuldt om bredere sammenhænge og strukturer. Jeg tager ikke i betænkning at citere Marx: „Mennesker skaber historien [konstruerer virkeligheden], men de gør det på betingelser, de ikke selv har skabt“. Det betyder ikke, at konkrete historiske forløb udfolder sig i en lovmæssig retning, men at der er nogle underliggende bestemmelser, som man kan indkredse og tage $\mathrm{i}$ betragtning.

Det er her vi er uenige, for Jørgensen bebrejder mig, at jeg sammenblander postmodernismen som samfundstilstand og som videnskabssyn. Postmodernismen er ikke en tidsperiode, men en videnskabsteoretisk position, påpeger hun. Hun vil skille teorien fra samfundsudviklingen. Her er det, jeg med alderdommens stivsind insisterer på, at de hænger sammen. Jeg tror ikke på, at postmodernismen er dalet ned fra det tomme rum som det afsluttende kapitel i videnskabsteoriens bog. Jeg tror, den i sine mangfoldige afskygninger er udtryk for nogle mentalitetsforhold, der beror på kræfter i samfundene. Når jeg hører røster, der hævder, at ,,der er ikke noget samfund“, ,,ideologierne er døde“", eller at vi har nået ,historiens endeligt“, så gnægger jeg: ,nyliberalist!“”. Og når man med begejstring forkynder, at „,der er ikke nogen virkelighed“, men at verden er et supermarked af meninger, så aner jeg en sammenhæng. Postmodernismen er nok et felt af videnskabsteoretiske tilgange, men den udtrykker også en tidsånd. Den afspejler efter mit bestik en fragmentation, en decentrering, en svækkelse af en fælles platform for samfundspolitisk teori efter årtiers infiltrering af markedsideologien.

Det var derfor, jeg slog til lyd for en genoprettet besindelse på social orden, solidaritet og retfærdighed. I et samfund, hvor man kan komme overens om grundlæggende sociale værdier og mål, har man etableret et fælles mål af enighed om en samfundsmæssig ,,virkelighed“. Så er der ikke længere kun en uendelighed af ,sandheder“ om verden, og samfundsforskere kan igen regne med et vist fælles grundlag af tillid, så de kan udtale sig med autoritet om samfundsmæssige sammenhænge og veje til at nå samfundets mål.

Og det må dog give mine synspunkter et vist gehør, at man med den foreliggende formulering har ladet dem trykke i nu to årtusinder.

John Liep

Institut for Antropologi Kфbenhavns Universitet 